\title{
Dalši informace o studii FIELD (Fenofibrate Intervention and Event Lowering in Diabetes)
}

Profesoři Špinar a Vítovec poskytli našemu časopisu informace o studii FIELD, opírající se o přednášku o této studii na kongrese American Heart Association v Dallasu v roce 2005. Jelikož studie FIELD byla již uveřejněna $\mathrm{v}$ časopise Lancet ${ }^{(1)}$ spolu s edičním článkem Lancetu, ${ }^{(2)}$ myslím, že je vhodné informace autorů doplnit.

Výsledky studie FIELD byly očekávány s velkým zájmem. Studie randomizovala 9795 pacientů s diabetes mellitus 2 . typu a výchozimi hodnotami celkového cholesterolu 3,0 až $6,5 \mathrm{mmol} / 1$ a $\mathrm{k}$ tomu bud' poměrem celkový cholesterol/HDL-cholesterol $\geq 4,0$ nebo hodnotami plazmatických triglyceridů mezi 1,0 až $5,0 \mathrm{mmol} / 1$ na léčbu $200 \mathrm{mg}$ mikronizovaným fenofibrátem nebo placebem. Do studie byli zařazeni jak pacienti bez anamnézy kardiovaskulárního onemocnění ( $\mathrm{n}=7$ 664), tak pacienti s anamnézou kardiovaskulárního onemocnění ( $\mathrm{n}=2131)$.

Žen bylo v souboru studie FIELD $37 \%$; 5820 (59 \%) pacientů studie vykazovalo nízké hodnoty HDL-cholesterolu (u mužů $<1,03 \mathrm{mmol} / \mathrm{l}$, u žen $<$ 1,29 mmol/1); 5093 (52\%) pacientů studie mělo zvýšené hodnoty triglyceridů ( $>1,7 \mathrm{mmol} / \mathrm{l})$. Průměrné trvání studie bylo pět let.

Léčba fenofibrátem vedla podle očekávání $\mathrm{k}$ významnému snížení triglyceridů o 29 \% a k mírnému snížení LDL-cholesterolu o $12 \%$; HDL-cholesterol se zvýšil na počátku studie ve skupině léčené fenofibrátem o $5 \%$, avšak toto zvýšení se $\mathrm{v}$ průběhu studie zmenšilo na pouhá $2 \%$.

Primárním cílem studie bylo zjistit, zda léčba mikronizovaným fenofibrátem (200 mg) povede oproti placebu k významnému snížení kombinace koronárních úmrtí + nefatálních infarktů myokardu. Studie FIELD bohužel tento primární cíl nesplnila. Ve studii došlo k 11\% snížení primárního cíle, které však nebylo statisticky významné. Léčba fenofibrátem sice významně snížila nefatální infarkty myokardu, ale koronární úmrtí byla nevýznamně o 19 \% vyšší ve skupině léčené fenofibrátem

Nelze vyloučit, že tyto výsledky mohly být způsobeny nerovnoměrným použiváním statinů. Po adjustaci na tento rozdíl bylo snížení primárního cíle statisticky významné a činilo $19 \%(p=0,01)$. Retrospektivní analýzu však musíme brát $\mathrm{s}$ rezervou, protože léčba statiny nebyla randomizována.

Je zajimavé, že nevýznamné snížení primárního cíle studie o $11 \%$ tvořilo jednak významné snížení primárního cíle o $25 \%$ u pacientů bez předchozího kardiovaskulárního onemocnění, tak i nevýznam- né zvýšení primárního cíle o $8 \%$ u pacientů s předchozím kardiovaskulárním onemocněním.

Ve studii FIELD však došlo k významnému snížení některých sekundárních cílů, které jsou uvedeny $\mathrm{v}$ tabulce autorů Špinara a Vitovce. Ze sekundárních cílů poklesl významně výskyt všech kardiovaskulárních príhod (ty zahrnovaly koronární úmrtí, nefatální infarkty myokardu, cévní mozkové příhody a revaskularizace koronární nebo karotid). Snížení všech kardiovaskulárních přihod bylo způsobeno hlavně významným sníženým výskytem nefatálních infarktů myokardu a významným snížením revaskularizací. Rozdíl se objevil po dvou letech trvání studie.

Výskyt všech kardiovaskulárních přihod byl nižší o 19 \% u osob bez dřivějšího kardiovaskulárního onemocnění, ale u osob s dřivějším kardiovaskulárním onemocněnim nebyl výskyt těchto príhod léčbou fenofibrátem významně ovlivněn.

Naproti tomu nebyla léčbou fenofibrátem ovlivněna koronární mortalita ani celková mortalita a tyto oba sekundární cíle vykazovaly nevýznamné trendy v neprospěch fenofibrátu. Výskyt cévních mozkových přihod byl nevýznamně nižší ve skupině léčené fenofibrátem o $10 \%$.

Rozdíly byly také zjištěny ve skupinách rozdělených podle věku $-<65$ let $\mathrm{a} \geq 65$ let. Zatímco $u$ pacientů mladších 65 let bylo zjištěno významné snížení všech kardiovaskulárních přihod o $20 \%(p=0,003)$, u pacientů starších nebyl rozdíl významný.

Celková mortalita a kardiovaskulární mortalita nebyly fenofibrátem významně ovlivněny. Úmrtí na jiné než kardiovaskulární přičiny byla ve skupině léčené fenofibrátem nevýznamně o 19 \% častější.

\section{Fenofibrát a albuminurie/retinopatie}

Terciárními cíli studie FIELD byl výskyt některých diabetických komplikací. U 539 (11\%) pacientů placebové skupiny došlo k progresi normoalbuminurie do mikroalbuminurie nebo $\mathrm{k}$ progresi mikroalbuminurie do albuminurie. Taková progrese se vyskytla významně méně často ve skupině nemocných léčených fenofibrátem ( $\mathrm{n}=466=9 \%$ ). Ústup albuminurie nebo mikroalbuminurie byl zjištěn u 400 (8\%) pacientů placebové skupiny a 462 (9\%) skupiny léčené fenofibrátem. Tyto nálezy ukazují, že 2,6 \% pacientů léčených fenofibrátem vykazovalo méně progrese nebo naopak regresi albuminurie. Tento rozdíl byl významný $(p=0,002)$.

Významně více pacientů $\mathrm{v}$ placebem léčené skupině muselo podstoupit laserovou léčbu retinopatie 
než ve skupině léčené fenofibrátem (5,2 \% vs. 3,6 \%, $p=0,0003$ ).

Tato snižení mikrovaskulárních komplikací diabetu nebyla dosud pozorována při léčbě statiny.

Léčba fenofibrátem byla dobře snášena, což nepřekvapuje; $90 \%$ uživalo fenofibrát po celou dobu trvání studie. Výskyt pankreatitidy byl však lehce významně vyšší ve skupině léčené fenofibrátem $(0,8 \%$ vs. $0,5 \%, p=0,032)$ a také plicní embolie se vyskytovala významně častěji ve skupině léčené fenofibrátem $(1,1 \%$ vs. $0,7 \%, p=0,022)$, i když absolutní počty byly nízké.

Výsledky studie představují jistě zklamání pro mnohé. Očekávalo se, že u diabetiků, jejichž lipidový profil se vyznačuje jen menším zvýšením LDL-cholesterolu, zato však významným zvýšenim triglyceridů, snížením HDL-cholesterolu a zvýšením malých denzních částic LDL-cholesterolu, budou výsledky léčby fenofibrátem přinejmenším rovnocenné výsledkům statinových studií u diabetiků pozorovaných ve studii CARDS s atorvastatinem (Collaborative Atorvastatin Diabetes Study) ${ }^{(3)}$ a diabetiků ve studii Heart Protection study se simvastatinem. ${ }^{(4)}$ Navíc předchozí studie s fibráty nasvědčovaly tomu, že by účinek fenofibrátu mohl být právě u diabetiků výrazný.

\section{Studie s ostatnimi fibráty}

V poslední době studie VA-HIT (Veterans Affairs High-Density Lipoprotein Cholesterol Intervention Trial) $^{(5)}$ docílila lepších výsledků než studie FIELD. Právě v této studii bránil gemfibrozil recidivám koronárních príhod více právě $u$ pacientů s diabetes mellitus nebo s metabolickým syndromem. ${ }^{(5)}$ Rovněž nedávno zveřejněná další analýza studie BIP (Bezafibrate Infarct Prevention) ${ }^{(6)}$ demonstrovala větší snížení kardiovaskulárních přihod u pacientů s metabolickým syndromem.

Autoři studie FIELD ke svému i našemu překvapení nezjistili rozdíly ve výsledcích mezi osobami s metabolickým syndromem či bez něho. Navíc snížení koronárních příhod (nefatálních) zjištěné ve studii FIELD bylo menši než ve zmíněných jiných studiích s fibráty studie VA-HIT ${ }^{(5)}$ a studie BIP. ${ }^{(6)}$

Také je vhodné uvést závěry nedávno uveřejněné metaanalýzy vlivu hypolipidemik a diety na mortalitu. ${ }^{(7)}$ Podle této metaanalýzy je jakékoliv možné snížení srdeční mortality vlivem fibrátů vyrovnáno zvýšeným rizikem úmrtnosti na jiná než kardiovaskulární onemocnění. ${ }^{(7)}$

Co říci závěrem? Studie FIELD přinesla některé překvapivé nálezy, které není snadné vysvětlit. Proč je účinek fenofibrátu větší u osob bez dřivějšîho onemocnění a chybí u pacientů v sekundární prevenci? Proč je účinek fenofibrátu u osob mladších 65 let a chybí u starších osob? Proč není účinek fenofibrátu větší u osob s metabolickým syndromem jako ve studii BIP s bezafibrátem? Proč je účinek fenofibrátu menší než gemfibrozilu, soudě podle výsledků studie VA-HIT? ${ }^{(5)}$

Autoři nedávají na tyto otázky uspokojivé vysvětlení. Připomínají však, že k určité heterogenitě studie mohla přispět léčba statiny u části nemocných a daleko menší zvýšení HDL-cholesterolu než které očekávali. Př́ijemným překvapením studie byl přiznivý účinek fenofibrátu na mikrovaskulární onemocnění diabetiků.
Ediční článek Lancetu ke studii FIELD ${ }^{(2)}$ se právem ptá: měli by být po studii FIELD léčeni diabetici fenofibrátem?, a zároveň na svou otázku odpovídá negativně. Americká guidelines ${ }^{(8)}$ doporučujî u diabetiků léčbu statiny, protože jejich účinnost je velmi dobře doložena. Je na místě připomenout hlavní výsledky statinových studií. Opírají se zejména o výsledky studie CARDS $^{(3)}$ a studie Heart Protection Study. ${ }^{(4)}$

Primárním cílem studie CARDS $^{(3)}$ byla doba do prvního vzniku následujících komplikací: akutní koronární syndrom, koronární revaskularizace nebo cévní mozková přihoda. Studie $\operatorname{CARDS}^{(3)}$ byla přerušena o dva roky dřive než bylo plánováno, primární cíl byl již v té době významně snížen o $37 \%(p=0,001)$. Medián trvání studie CARDS činil 3,9 let. Celková mortalita byla ve skupině nemocných léčených atorvastatinem snížena o $27 \%(p=0,059)$. Akutní koronární př́ihody byly ve studii CARDS (10 mg atorvastatinu) sniženy o $36 \%$, cévní mozkové příhody dokonce o $48 \%$. Nálezy studie $\operatorname{CARDS}^{(3)}$ odpovídaji nálezům studie Heart Protection Study, ${ }^{(4)}$ ve které bylo zjištěno u několika tisíc pacientů s diabetes mellitus 2. typu (bez předchozí okluzivní cévní choroby) snížení relativního rizika léčbou $40 \mathrm{mg}$ simvastatinu oproti placebu o $33 \%$ ( $p=0,0003)$.

U nemocných s izolovanou výraznou hypertriglyceridemií budou jistě fibráty léky volby a u rady nemocných s ICHS a kombinovanou hyperlipidemií bude jistě kombinace statinu a fibrátu vítanou a účinnou léčbou. Ale účinnost této kombinace na celkovou mortalitu a kardiovaskulární mortalitu zatím známa není. Tato kombinace se jeví logická $\mathrm{u}$ pacientů $\mathrm{s}$ kombinovanou hyperlipidemií. Naše dřivější jednoroční zkušenosti s kombinací fluvastatinu a fenofibrátu ukázaly jak větší hypolipidemickou účinnost, jako i dobrou snášenlivost, ${ }^{(9,10)}$ nebyly to však mortalitni studie.

Již probíhající mortalitní studie ACCORD porovnávající účinnost kombinace statin + fibrát oproti monoterapii statinem $\mathrm{u}$ pacientů $\mathrm{s}$ diabetes mellitus nám, doufejme, tyto informace přinese..$^{(1)}$

prof. MUDr. Jiři Widimský, DrSc., FESC, ČLA, Klinika kardiologie IKEM, Praha

\section{LITERATURA}

1. The FIELD study investigators. Effects of long-term fenofibrate therapy on cardiovascular events in 9795 people with type 2 diabetes mellitus (the FIELD study): randomised controlled trial. Lancet 2005;366:1849-61.

2. Colhoun H. After FIELD: should fibrates be used to prevent cardiovascular disease in diabetes? Lancet 2005; 366:1829-31.

3. Colhoun HM, Betteridge DJ, Durrington PN, for the CARDS Group. Primary prevention of cardiovascular disease with atorvastatin in type 2 diabetes in the Collaborative Atorvastatin Diabetes Study (CARDS): multicentre randomised placebo-controlled trial. Lancet 2004;364:685-96.

4. Collins R, Armitage J, Parish S. for the Heart Protection Study Collaborative Group. MRC/BHF Heart Protection Study of cholesterol-lowering with simvastatin in 5963 people with diabetes: a randomised placebo-controlled trial. Lancet 2003;361:2005-16. 